\title{
PRODUCTION OF MEAGRE IN EARTHEN PONDS
}

\author{
A.E. Eid ${ }^{1}$, Badea A. Ali ${ }^{1}$, Amal Elfeky ${ }^{1}$, Walaa K. Bazina ${ }^{2}$ and Heba Saleh ${ }^{1}$ \\ 1. Dept. of Animal and Fish Resources, Faculty of Agriculture, Suez Canal University, Ismailia 41522- \\ Egypt.
}

2. Fish Breeding Laboratory, National Institute of Occenography and Fisheries, Hurgada, Egypt.

(Received 29/10/2019, accepted 26/12/2019)

\section{SUMMARY}

\begin{abstract}
$\mathrm{T}$ The present study investigated the effect of rearing the meagre, Argyrosomus regius in brackish-water pond aquaculture without using supplementary feeding in the Mediterranean area near Damietta City during June, 2017 to June, 2018, Fingerlings of mean length $13.0 \mathrm{~cm}$ and $40.0 \mathrm{~g}$ weight were stocked in brackish-water pond measuring 1 feddan and $1.25 \mathrm{~m}$ deep at a rate of $4000 \mathrm{fish} /$ feddan in a monoculture system on natural occurring prey (natural spawned tilapia) and small shrimp. Temperature varied from $21.0-30.8^{\circ} \mathrm{C} ; \mathrm{pH}, 7.4-8.9$; Dissolved Oxygen (DO), $4.0-5.0 \mathrm{mg} / \mathrm{L}$ and salinity, $16.0-18.8 \mathrm{ppt}$ during the study. Meagre, attained average final length $40 \mathrm{~cm} /$ fish and average final weight $1500 \mathrm{~g} / \mathrm{fish}$ at harvest with an increment of $1460.0 \mathrm{~g} / \mathrm{fish}$ and a daily gain of $4.0 \mathrm{~g} / \mathrm{fish}$. Average survival rate was $80 \%$ and net production was $4640.0 \mathrm{~kg} /$ feddan. The resultsrevealed that the cost of feeds accounted for the largest proportion $(68.55 \%)$ of the total cost of fish production,then fingerlings $(8.56 \%)$, rent $(3.35 \%)$ and labor $(12.60 \%)$. This is followed by cost of fixed input and variable coast $(12 \%)$. This experiment demonstrated the possibility of cultivation of $A$. regius as well as the higher commercial value where better net return $(54.48 \mathrm{LE} /$ feddan) was recorded with investment return of $23.33 \mathrm{LE} /$ return LE cost. The results of the study indicated meagre as a promising candidate for the brackish water pond aquaculture.
\end{abstract}

Keywords: Meagre, production, ponds growth and economical analysis.

\section{INTRODUCTION}

Meagre (Argyrosomus regius) is receiving currently special attention due to the necessity of species diversification in Mediterranean mariculture (Duncan et al., 2013)

Meagre (meager) proved to be a new candidate in Egyptian aquaculture. The preliminary efforts to adapt Meagre to aquaculture were done by the private sector, starting in 1996 in Damietta Governorate. Ongoing meagre farming operations rely on trash fish and small shrimp as the only feeding source whereas a harvest of about 12 tons/ha have been achieved over 285 days with $1.25 \mathrm{~kg}$ as an average weight/fish. In this situation and as expected, the feed conversion ratio is poor with an average of 9 (feed): 1 (gain).

Because there is a growing interest to incorporate meagre in Egyptian aquaculture, there is a new initiative that targets the artificial spawning and production of meagre seeds. Also, field trials have been conducted on private farms for evaluating the impact of artificial feed with 40 and $50 \%$ crude protein on the growth performance and production of the species. These initiatives are expected to support the development of meagre aquaculture in Egypt whether for local market and possibly for export.

Meagre production has increased rapidly in recent years, mainly due high flesh quality and flavour, fast growth, large sizes, high feed conversion rate and high adaptation capacities to environmental changes (Duncan et al., 2013). Egypt is the most important producer of meagre, which is cultured in brackish-water ponds, as a capturebased aquaculture using fingerlings and juveniles from the Nile delta (El-Sheblyet al., 2007). In many other Mediterranean countries, 
however, meagre is grown-on in coastal floating net pens, using fingerlings from different hatcheries. However, meagre is a fast growing species with a good taste and has a tremendous potential for culture in brackish water ponds (FAO, 2002). Moreover, Sadek and Baraneya (1993) referred to the importance of the area at Damietta City in marine culture where brackish water fish farms are widely distributed. Earlier, (Gracia et al., 2002) recorded that meagre grow very fast in the cages in brackish water ponds in Egypt. The Egyptian Mediterranean coast, Port Said is considered as one of the most productive fishing ground. About $25 \%$ of the total fish production in the Egyptian Mediterranean sector comes from Port Said. Port Said derives its fish production from four main resources; Mediterranean Sea, Lake Manzala, Port Fouad Lake and aquaculture with main annual fish production of about 8000, 1500, 170 and 15000 ton, respectively (GAFRD, 2006). It is obvious that fish production of aquaculture sector (represented by licensed fish farms) exceeds that of fisheries by about one and half times.

Feed expenditure constitute $30-70 \%$ of total expenditure in fish culture and for this reason different methods have been essayed to gain benefit from every kind of feed source especially in the countries with developed aquaculture sector (Ruiz-Jaraboet al., 2019 and Ferdoushiet al., 2019).

The overall goal of the aquaculture is to reduce production costs, maximize production and increase profitability (Hossain et al., 2007). This present study was carried out to assess the potential of the meagre for culture under the existing conditions in the brackish-water without use of supplementary feeding, under earthen pond systems in Egypt.

\section{MATERIALS AND METHODS}

\section{Study site and experimental units:}

The experiment was done in collaboration with a private fish farm located at Damietta Governorate with an area of 1 feddans and a water depth of about $1.25 \mathrm{~m}$ during June, 2017 to June, 2018. The water in this farm is a brackish due to the mixing of Mediterranean Sea waters and waters from Lake Manzala. Productivity was based on the natural productivity of the ponds hence the experimental ponds were kept free from any shading throughout the day.

\section{Water quality:}

Sampling for physico-chemical parameters was done once a week between 09.00 and 12:00 h from specific points of the pond at a depth of $20-30 \mathrm{~cm}$ below the surface.A mercury thermometer was used to measure water temperature $\left({ }^{\circ} \mathrm{C}\right)$, while salinity (psu) was measured with a salinometer. Digital electronic meters (Model YSI-58, USA and Jenway Model-3020) were used to measure Dissolved Oxygen (DO) (mg-1) and $\mathrm{pH}$ on site, respectively, according to the standard procedures and methods as defined in APHA (1992).

\section{Fish stocking and sampling:}

The fingerlings were obtained from the coastal area of Mediterranean Sea and Northern shores of Lake Manzala, during June, 2017 with an average initial body weight of $40.0 \mathrm{~g} /$ fishand average initial lengths of $13.0 \mathrm{~cm} / \mathrm{fish}$. The pond was stocked with the fingerlings of meagre at the rate of $4000 \mathrm{fish} /$ feddan in a private fish farm located at Damietta Governorate. Before stocking $A$. regius fingerlings, the experimental pond was stocked with sardine and tilapia in polyculture systems to provide nutrition for the cultured fish, preying the occurring prey of spawned tilapia and sardine fingerlings in the ponds. Additional feeding supplement was done with wild collected Tilapia zillii and small shrimps of the Palaemon spp.

Twelve random samples of the fish were taken during the study period (12 samples/ year), where 15-20 fingerlings meagre were randomly sampled monthly. The samples were measured for weight and length to the nearest $0.01 \mathrm{~g}$ and $0.01 \mathrm{~cm}$, respectively.

At the end of experiment, the pond was harvested and counted, weighted and length measurements taken. To ensure complete harvest, the meagre were harvested initially by netting and any remaining individuals harvested by complete draining of the earthen ponds and hand picking any meagre in the ponds. 


\section{Growth performance parameters:}

Fish growth, expressed as daily increment in weight (g/fish) or the increase in body weight per day (\%/ day) was calculated based the following formula:

$$
\text { DGR }=(\mathrm{W} 2-\mathrm{W} 1) / \mathrm{t}
$$

Where: $\mathrm{W} 1=$ The initial live body weight $(\mathrm{g}), \mathrm{W} 2=$ The final live body weight $(\mathrm{g}), \mathrm{t}=$ The time in days.

Total weight at stocking $\mathrm{Kg} / \mathrm{feddan}=\mathrm{No}$ of fish stocked $\mathrm{X}$ Average weight at stocked

Total weight at Harvest $\mathrm{Kg} / \mathrm{feddan}=\mathrm{No}$ of fish at harvest $\mathrm{X}$ Average weight at harvest

Net production $=$ Total weight at Harvest $\mathrm{Kg} /$ feddan - Total weight at stocking $\mathrm{Kg} /$ feddan

$\mathrm{FCR}=$ Feed intake $(\mathrm{g}) /$ weight gain $(\mathrm{g})$

Feed Intake (FI):-Amount of consumed feed per period

\section{Survival rates (\%):}

Survival rates (\%) were estimated as: No. of fish harvested/No. of fish stockedx 100. Net production (kg feddan-1) was calculated by deducting the biomass stocked from the biomass harvested.

The mean fish weight $(\mathrm{g})$ was determined in terms of gain in weight:

$$
\mathrm{GW}=(\mathrm{W} 2-\mathrm{W} 1) / \mathrm{W} 1 \times 100
$$

Where: $\mathrm{W} 1=$ The initial live body weight $(\mathrm{g}), \mathrm{W} 2=$ The final live body weight $(\mathrm{g})$

The condition factor $(\mathrm{CF})$ is determined according to the equation:

$$
\mathrm{CF}=(\mathrm{W} / \mathrm{L} 3) \times 100
$$

Where: $\mathrm{W}=$ The body weight $(\mathrm{g}), \mathrm{L}=$ The length of the fish $(\mathrm{cm})$.

\section{Economical analysis:}

Methodology: A private fish farm located at Damietta Governorate with an area of 1 feddans and a water depth of about $1.25 \mathrm{~m}$ during June, 2017 to July, 2018

\section{Fish production information:}

Fingerlings source, costs and quantities

Pond aeration

- Labor

$$
\text { Fish production }
$$

Fingerligs cost $=$ No $X$ price of each

Feed cost $=$ amount of feed $X$ price

Total production $(\mathrm{kg} / \mathrm{feddan})=$ weight of fish No of fish at Harvest

Total income LE feddan= Total production $(\mathrm{kg} /$ feddan $) \mathrm{X}$ price of $\mathrm{Kg}$

Net return LE feddan= Total income LE feddan- Total cost

A simple economic analysis was performed to estimate the profitability from this experiment. Total investment costs were calculated and the net revenue was determined by the difference between the gross revenue and the total investment costs. This analysis was based on farm gate prices of meagre and current local market prices expressed in Egyptian LE.

\section{RESULTS AND DISCUSSION}

\section{Physico-Chemical Parameters:}

Mean values of some water quality parameters such as temperature, $\mathrm{pH}$, dissolved oxygen and salinity were calculated to provide an overview of changes in the meagre culture earthen 
pond during the experimental period as shown in Table (1). Water temperature varied from 21.0 to $30.8^{\circ} \mathrm{C}$ with an average of $25.9^{\circ} \mathrm{C}$ during the study depending upon environmental variation .

Table (1): Water quality parameters for fish pond in Eldebba Port Said governorate (12 month).

\begin{tabular}{lcccc}
\hline Month & DO mg/L & Salinity $(\mathrm{ppt})$ & Temperature ${ }^{\circ} \mathrm{C}$ & $\mathrm{pH}$ \\
\hline June 2017 & 5.00 & 16.00 & $28 . .20$ & 8.00 \\
July & 4.9 & 17.50 & 30.00 & 7.90 \\
August & 4.50 & 18.50 & 30.80 & 7.40 \\
September & 4.0 & 18.80 & 30.10 & 7.50 \\
October & 4.0 & 18.20 & 25.20 & 8.00 \\
November & 4.2 & 18.50 & 22.20 & 8.10 \\
December & 4.90 & 18.20 & 22.00 & 8.20 \\
January 2018 & 4.9 & 18.20 & 22.00 & 8.9 \\
February & 4.20 & 18.5 & 21.00 & 8.00 \\
March & 4.10 & 18.00 & 21.80 & 8.20 \\
April & 4.20 & 18.50 & 25.70 & 8.10 \\
May & 4.10 & 18.00 & 27.00 & 8.10 \\
\hline
\end{tabular}

The water $\mathrm{pH}$ varied from 7.4 to 8.9 with an average of 8.15 and Dissolved Oxygen (DO) content varied from 4.0 to $5.0 \mathrm{mg} / \mathrm{L}$ with an average of $4.5 \mathrm{mg} / \mathrm{L}$. Water salinity ranged from 16.0 to $18.8 \mathrm{ppt}$ with an average of $17.4 \mathrm{ppt}$ depending upon the tide in the lake, drainage water discharged into the lake and the seasonal variations. The variations of $\mathrm{pH}$ and dissolved oxygen were more or less similar $(\mathrm{p}>0.05)$ among the months and within the productive range, although the variations in salinity was significantly $(\mathrm{p}<0.05)$ different. The variations of water temperatures are attributed to weather conditions and statistical tests showed significantly differences $(\mathrm{p}<0.05)$ in temperatures among the month during the study. The observed average temperatures were within the optimal ranges $\left(21.0-34.0^{\circ} \mathrm{C}\right)$ for fish production in tropical ponds (Begum et al., 2003; Hossain et al., 2006). However, the best temperature for the growth of meagre is between $17-21^{\circ} \mathrm{C}$ and feeding activity is substantially reduced when water temperatures drop below $13-15^{\circ} \mathrm{C}$ (FAO, 2002; FAO, 2014). Quemener (2002) also recorded the similar findings that the rapid growth of meagre, A. regius was between 16 and $20^{\circ} \mathrm{C}$. On the other hand, Boyd (1992) recommends optimal temperature for fish culture, in the range 26.06$31.97^{\circ} \mathrm{C}$, if fish growth and consequently yields are to be optimized. It should also be indicated that temperature alone may not account for variations in plankton as well as fish production, other factors such as high $\mathrm{pH}$, alkalinity, carbon dioxide and nutrients are also responsible for the organic production (Pulle and Khan, 2003; Hossain et al., 2007; Begum et al., 2007). The variations in $\mathrm{pH}$ and dissolved oxygen were similar $(\mathrm{p}>0.05)$ and within the productive range (Wahab et al., 1994; El-Shebly et al., 2007; Hossain et al., 2007), although the variations of salinity were significantly $(\mathrm{p}<0.05)$ difference among the month. In this study, the fluctuation in water salinity was dependent on percentages of mixing of sea water and Lake Manzala water (El-Hehyawi, 1974). And also it was controlled by wind direction and tides. The present study is the first to propose that brackish water may be more appropriate for the culture of A. regius fingerlings than seawater. This information is relevant to the aquaculture industry as optimizing environmental salinities for this species could improve growth rates, resulting in economic advantages. Estuaries are associated with the life history of the meagre, and meagre juveniles are mostly found in brackish waters (Morales-Nin et al., 2012).

\section{Growth and production of Meager:}

The meagre is one of the most valuable commercial fish for aquaculture (Poli et al., 2003). The present study deals with the possibilities of cultivation of meagre in earthen ponds without any supplementary feeding in Egypt. The possibilities of cultivation of meagre (A. regius) in the Mediterranean area in brackish water fish farms near Damietta city, Egypt has been observed by this experiment. Earlier, Sadek and Baraneya (1993) referred to the importance of the area at Damietta city in marine culture where marine and brackish water fish farms are widely distributed. The meagre is one of the most valuable commercial fish for aquaculture (Poli et al., 2003). The growth performance of the $A$. regius in terms of initial weight, final weight, initial total length, final total length, stocking rate, survival rates, daily increment in weight and total production in Eldeeba port Saied Governorate fish farm are 
shown in Table( 2). The fish attained an average final weight of $1500 \mathrm{~g}^{-1} \mathrm{sh}^{-1}$ and an average final length of $40.0 \mathrm{~cm} \mathrm{fish}^{-1}$ at the end of the rearing period (365days). The fish attained an increment in weight of $1460.0 \mathrm{~g} /$ fish with daily gain of $4.0 \mathrm{~g} /$ fish and a percentage gain in weight of 365/ fish. Risk and Hashem (1981) recorded a length of $28 \mathrm{~cm}$ after the first year culture under the Egyptian conditions. (Osman and Sadek, 2002) recorded an individual weight of $724.5 \mathrm{~g} \mathrm{fish}^{-1}$ in 300 days for meagre. The present results were better than the findings recorded by Risk and Hashem (1981) and Osman and Sadek (2002). The daily gain in weight and specific growth rate and condition factor in the present study was $4.0 \mathrm{~g} / \mathrm{fish}, 6.3$ and 3.75 . The highest daily gain of meagre was recorded from the same area where other marine fishes such as Sea bream (Sparusaurata) attained a daily gain of $0.73 \mathrm{~g} /$ fish (El-Shebly and Siliem, 2003) and Sea bass (Dicentrarchuslabrax) attained a daily gain of $1.13 \mathrm{~g} /$ fish (El-Shebly, 2005).

Table (2): Growth performance of the meagre, Argyrosomusregius reared in brackish water fish farms at Damietta, Egypt during June, 2017 to May, 2018.

\begin{tabular}{lc}
\hline Parameter & Rate \\
\hline Average Initial weight $(\mathrm{g})$ & 40.00 \\
Average Final weight $(\mathrm{g})$ & 1500 \\
Weight gain $(\mathrm{g})$ & 1460.0 \\
Weight gain/day & 4.00 \\
Weight gain (\%) & 365.00 \\
SGR in weight & 6.3 \\
Average initial length $(\mathrm{cm})$ & 13.00 \\
Average final length $(\mathrm{cm})$ & 40.00 \\
Average gain length $(\mathrm{cm})$ & 27.00 \\
SGR in length & 2.99 \\
Survival rate $(\%)$ & 80.0 \\
Rearing period (day) & 365 \\
Total weight at stocking ton/feddan & 160.00 \\
Total weight at Harvest Kg/feddan & 4800.00 \\
Net production Kg /feddan & 4640.00 \\
Feed intake (ton / feddan) & 10.22 \\
Feed conversion & 7.00 \\
Condition factor (CF) & 4.27 \\
\hline
\end{tabular}

This may be due to different fish species or environmental conditions. This fish were fed on trash fish Tilapia zillii which contain a high content of protein. Earlier it was reported that meagre primarily feed on schooling fish such as sardine (Cabral and Ohmert, 2001). Further, (Quero and Vayne,1985,1987) reported that in wild, the young meagre (A. regius) feed on small crustaceans and the adults on pelagic fishes. The optimum growth and feed efficiency of marine fish can be achieved by providing large amounts of protein (40-60\%) in the diet (Tibaldi and Lanari, 1991 and El-Shebly et al., 2007). In general, marine fish require higher dietary protein diets than other fishes. Peres and Oliva-Teles (2003) recorded that the reduction of dietary protein level not only affect growth rate but also increased feed intake and decreased feed efficiency for marine fish. During this study, it was recorded the feed conversion ratio was 7:1 which was higher to that reported by (Manomaitis and Cremer, 2007) with an FCR value of 1.84 and (Lanet al., 2008) from 2.51 to 2.59 (McMaster et al., 2008) with FCR value of 3.0 and (Cremer and Jian, 1999) with 2.13 and 2.23 with pompano This may be due different feeding trash fish and environmental condition or fish species.

The survival rate was $80 \%$. The total production was $4800.00 \mathrm{~kg} / \mathrm{feddan}$ with net production of $4640.00 \mathrm{~kg} /$ feddan. This higher survival rates was partly because of the favorable conditions and the good water quality, beside the average initial weight and length which were high $(20.20$ $\mathrm{g}$ and $12.80 \mathrm{~cm})$. In agreement with El-Shebly et al. (2007).

To show the economical value of fish culture, some economical aspects has been taken into consideration: 1) The production, 2) The cost of culturing, 3) The quality and size of the fish for marketing. The economic evaluation (Table 3). 
The study examines the profitability of fish production in the study area. To determine the profit level, attempts were made to estimate the cost and return from fish farming (Table 3). The input used, cost, yield or output data generated from the farmers were used to undertake the cost and return analysis for assessing the profitability of fish production in the study area.

Table (3): Average cost and return of fish production.

\begin{tabular}{lcc}
\hline Item & Rate & Percent \\
\hline Costs feddan & & \\
Fingerlings costs LE & 20.000 & 8.56 \\
Feed cost LE & 163.52 & 68.55 \\
Labour and other costs LE & 30.000 & 12.60 \\
Rent & 8.000 & 3.35 \\
Solar & 12.000 & 5.03 \\
Total costs LE feddan & 233.52 & \\
Income feddanLE & & \\
Total production (ton /feddan) & 4.800 & \\
Price (LE) of one kg fish & 60 & \\
Total income LE/ feddan & 288000 & \\
Net return LE/ feddan & 287.87 & \\
Investmental return LE/ return LE cost & 1.233 & \\
\hline
\end{tabular}

The result revealed that the cost of feeds accounted for the largest proportion $(68.55 \%)$ of the total cost of fish production.Similar results were obtained by Rahman et al. (2012). Then fingerlings (8.56\%), rent $(3.35 \%)$ and labor $(12.60 \%)$. These were followed by cost of fixed input and variable coast $(12 \%)$. This clearly shows that large fish farmers in the study area for purchase feeds spend amount of money. The fixed cost of production consists of cost of fixed assets such as pump, and pond rented which accounted for $12 \%$ of total production cost. These agreement with Ferdoushiet al. (2019). On the other hand, labor cost was found the second major cost. Boatenget al. (2013) also observed labor cost (10\%) as second major proportion of the total of tilapia production following feeding cost. However, labor cost would vary under each particular case, location, species, experimental conditions and season.

These results are with the finding of Ashaolu et al. (2006) from their studies on profitability on fish farming. The rate of return per capital invested (RORCI) is the ratio of profit to total cost of production. It indicates what is earned by the business by capital outlay (Awotideand Adejobi, 2007). The result revealed that the average RORCI of $1.233 \%$ is greater than the prevailing bank lending rate $8 \%$ implying that fish farming in the study area is profitable (Table 3). If a farmer takes loan from the bank to finance fish farming, he will get profit after paying back the loan at the prevailing interest rate. Fish culture gives higher returns in money and food than rising of cattle, sheep and poultry (Hickling, 1962). The result of the present study has been shown the higher production of meagre and accordingly the higher income which means that investment in this field of production is profitable. Finally, the present study concluded that meagre may be a promising candidate for the brackish water pond aquaculture in Egypt as well as other parts of the world.

\section{CONCLUSION}

This recommendations flow directly from the challenges and critical factors that farmers facing in the survey area, which indicate that meagre production is economically rewarding and profitable despite problems and challenges. It is available and attractive to who want to invest in this area and improving the standard of living of the people.

\section{REFERANCES}

APHA (1992). Standard Methods for the Examinations of Water and Wastewater. American 
Ashaolu, O.F.; A.A. Akinyemi and L.S. Nzekwe (2006). Economic viability of homestead fish production in Abeokuta Metropolis of Ogun state, Nigeria. Asset Series A, 6(2), 209-220. Central Bank of Nigeria 2004. Statistical Bulletin, 264- 267.

Awotide, D.O. and A.O. Adejobi (2007). Technical efficiency and cost of production among plantain farmers in Oyo State Nigeria, Moor Journal of Agricultural Science, 7 (2): 107-113.

Begum, M.M; M.A. Hossain; Z.F. Wahab and A.H. Kohinoor (2003). Effects of iso-phosphorus fertilizers on water quality and biological productivity in fish pond. J. Aqua. Trop.18:1-12. Begum, M..Y; Hossain; Z.F .Wahab; M.J. Ahmed; M.M .Alam and S. Jasmine (2007). Effects of isonutrient fertilization on plankton production in earthen ponds of Bangladesh. Pak. J. Biol. Sci., 10: 1221-1228.

Boateng, V.F., E.H. Alhassan, Y. Saahene, E. Nensom and E.D. Abarike (2013). Profitability Analysis of all-male Tilapia Farming in Sekyere South and Bosomtwe Districts of Ashanti Region. Agriculture and Biology Journal of North America, 4(5): 568-575.

Boyd, C.E. (1992). Water Quality Management of Pond Fish Culture. Elsevier Sci. Publ. Co. AmsterdamOxford, New York, pp: 318.

Cabral, H.N. and B. Ohmert (2001). Diet of the Juvenile meagre (Argyrosomus regius), within the Tagus estuary. Cahiers-de-Ecologie Marine, 24: 289-293.

Cremer, M.C. and Z. Jian (1999). Pompano (Trachinotus ovatus) Growth Performance in $1.5 \mathrm{~m} 3$ Cages with Soybean Meal and Fish Meal Based Feed Rations. Results of ASA/China, Feeding Trial, 35, 9973.

Duncan, N.J; A. Estévez ; H .Fernández-Palacios； I. Gairin ； C.M. HernándezCruz ; J .Roo ; D. Schuchardt and R. Vallés (2013). Aquaculture production of meagre (Argyrosomus regius): Hatchery techniques, ongrowing and market. In: Alan Gand Gavin B, editors. Advances in Aquaculture Hatchery Technology. Cambridge UK: Woodhead Publishing, p. 519-41.

El-Hehyawi, M.L.E. (1974). Changes in salinity and landings of six species in the shelf, North to the Nile Delta. Bull. Inst. Oceanography Fish. Egypt, 4: 435-458.

El-Shebly, A.A. (2005). Studies on growth and production of sea bass (Dicentrarchuslabrax) reared in brackish water fish farms. J. Egypt. Acad. Soc. Environ. Develop. (B- Aquaculture), 6: 19-30.

El-Shebly, A.A and N.A. Siliem (2003). Studies on growth and production of sea bream (Sparusaurata )in brackish water fish farms. Bull. Nat. Instit. Oceanography Fish. A.R.E., 29: 267-279.

El-Shebly, A.A.; M.A.H. El-Kady and M.Y. Hossain (2007). A preliminary observation on the pond culture of European Eel, (Anguilla Anguilla) (Linnaeus, 1758) in Egypt: recommendations for future studies. Pak. J. Biol. Sci., 10: 1050-1055.

El-Shebly, A.A.; A.H.M. El-Kady; B. H. Abdalla and M.Y. Hossain (2007). Preliminary Observations on the Pond Culture of Meagre, Argyrosomus regius (Asso, 1801) (Sciaenidae) in Egypt. Journal of Fisheries and Aquatic Science, 2: 345-352.

FAO (2002). Food and Agricultural Organization. Cultured aquatic species information programme Argyrosomusregius. http://www.fao.org/fi, accessed date: 7 May, 2007.

FAO (2014) Cultured Aquatic Species Information Programme. Argyrosomusregius. Cultured Aquatic Species Information Programme. Text by Stipa, P., Angelini, M. In:

Ferdoushi, Z; P.Patwary ; Y. Ara and M. Rana (2019). Economic analysis of tilapia farming in some selected area of Dinajpur District: A comparison between monoculture and polyculture J Bangladesh AgrilUniv 17(1): 117-121,

GAFARD (2006). Statistics of fish production GAFARD Ministry of Agriculture and Land Reclamation. Gracia, F; A. Jofer; E. Pascual ; Y .Sanchez and S. Rey (2002). Preliminary studies on growth of meagre, (Argyrosomus regius) (Asso, 1810) in sea cages and indoor tanks. Aquaculture Europe, 2002, Sea Farming Today and Tomorrow, pp: 422-423. Hickling, C.F.(1962). Fish Culture. Faber and Faber, London. 295p

Hossain, M.Y; M. Begum; Z.F .Ahmed; M.A. Hoque; M.A. Karim and M.A. Wahab (2006). A study on the effects of iso-phosphorus fertilizers on plankton production in fish ponds. South Pac. Stud., 26: $101-110$. 
Hossain, M.Y; S. Jasmine; A.H.M. Ibrahim; Z.F. Ahmed and J.Ohtomi (2007). A preliminary observation on water quality and plankton of an earthen fish pond in Bangladesh: Recommendations for future studies. Pak. J. Biol. Sci., 10: 868-873.

Lan, H.P; M.C. Cremer; J .Chappell ; J .Hawke and T. O'Keefe (2008). Growth performance of Pompano (Trachinotusblochii) Fed Fishmeal and Soy Based Diets in Offshore OCAT Ocean Cages. Results of the 2007 OCAT Cage Feeding Trial in Hainan, China.

Manomaitis, L and C.M. Cremer (2007). Performance of Pompano Fed Soy-Optimized,Extruded Feed Using ASA-IM Low Volume High Density Cages in Vung Tau Province, Vietnam. Results of ASAIM/Soy-in-Aquaculture 2007, Feeding Demonstration Project.American Soybean International Marketing (ASA-IM).

McMaster, M.F; T.C. Kloth; J.F. Coburn and N.E. Stolpe (2008). Florida Pompano (Trachinotuscarolinus) Is an Alternative Species for Low Salinity Shrimp Pond Farming.In: Aquaculture America 2006. Mariculture Technologies International Inc.

Morales-Nin, B; A.J. Geffen; S .Perez-Mayol; M .Palmer; R .Gonzalez-Quiros and A. Grau (2012). Seasonal and ontogenic migrations of meagre (Argyrosomus regius) determined by otolith geochemical signatures. Fish. Res., 127-128, 154-165

Osman, M.F and S. Sadek (2002). Meagre (Argyrosomus regius Asso, 1801) A new candidate in Aquaculture (short notes). Proceedings of the 1st Scientific Conference of the Egyptian Aquaculture Society, Faculty of Environmental Agricultural Sciences, December 13-15, 2002, El-Arish, North Sinai, Egypt, pp: 7-.

Peres, H and A. Oliva-Teles (2003). The effect of dietary ribonucleic acid incorporation in performance of European sea bass (Dicentrarchuslabrax) juvenile. Aquaculture, 215: 245-253.

Poli, B.M; G. Parisi; G. Zampacavallo; F.Iurzan; M.Mecatti; P. Lupi and A.Bonelli (2003). Preliminary results on quality and quality changes in reared meagre (Argyrosomus regius): Body and fillet traits and freshness in refrigerated commercial-size fish. Aquacult. Int., 11: 301-311.

Pulle, J.S and A.M. Khan (2003). Phytoplanktonic study of Isapur dam water.Eco. Environ. Cons., 9: 403-406.

Quemener, L. (2002). Meagre (Argyrosomus regius): Biology, Fisheries, Market and Rearing Potential. Resources-de-La-mer-IfremerPlouzane-France, France, pp: 31.

Quero, J.C and J.J. Vayne (1985). The mearge (Argyrosomus regius) from the Bay of Biscay and farm more septentional waters. Rev. Trav. Peches-Marit. Nantes, 49: 35-66.

Quero, J.C and J.J. Vayne (1987). The meagre, Argyrosomus regius (Asso, 1801) (Pisces,Perciformes, Sciaenidae) from Gulf of Gascony and some more Northern waters.Mag. Jobs Instit. Maritime Peches, 49: 35-66.

Rahman, M.M., M.Shamsuzzaman; S.Mahmood; S. Sarker and F.Alam (2012). Economics of Tilapia Culture in Watershed Pond in Bangladesh. Journal of Aquaculture Research and Development, 3(5): 1-5.

Risk, M.H and M.T.Hashem (1981). Some biological aspects of Sciacnaaquilla Risso in Abu-Kir Bay. Bull. Instit.Oceanography Fish. A.R.E., 7: 505-516.

Ruiz-Jarabo,I; A.B.Tinoco; L.Vargas-Chacoff; J.A.Martos-Sitcha; A.Rodríguez-Rúa ; S. Cárdenas and J.M. Mancera (2019). Environmental Salinity Affects Growth and Metabolism in Fingerling Meagre (Argyrosomus regius) Fishes, 4, 6; 2-11.

Sadek, S and A. Baraneya (1993). Evaluation of Egyptian trial in aquaculture. Proceedings of the Fish Culture Workshop, April 11-14, 1993, Riyadh, Saudi Arabia, pp: 27-.

Tibaldi, E and L. Lanari (1991). Optimal dietary lysine levels for growth and protein utilization of juvenile sea bass Dicentrarchuslabrax fed semi-purified diets. Aquaculture, 95: 297-304.

Vargas-Chacoff, L; I. Ruiz-Jarabo ; I .Páscoa ; O .Gonçalves and J.M .Mancera (2014). Yearly growth and metabolic changes in earthen pond-cultured meagre Argyrosomusregius. Sci Mar. 78:193-202.

Wahab, M.A; M.T. Islam; Z.F.Ahmed; M.S. Hoque; M.A .Hoque and B.K. Biswas (1994). Effects of frequency of fertilizers on the pond ecology and growth of fishes. BUA Res. Prog., 9: 410-419. 
عبد الحميد عيد1 ، بديعة عبد الفتاح على1 ، امال الفقى1 ، ولاء بازينة22 و هبه صالح3

الفسم الاتتاج الحيوانى والثروة السككية ـ كلية الزراعة- جامعة قناة السويي- الاسماعيليه 41522- مصر.

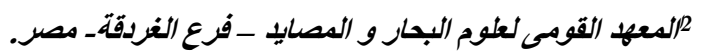

3 3معه استزراع و تكنولوجيا الاسماكـ جامعة قناة السويس-بالاسماعلية- مصر.

اجريت هذه الدراسة لمعرفة تأثير نربية سمك اللوت Argyrosomus regius في أحو اض المياه المالحة دون استخدام

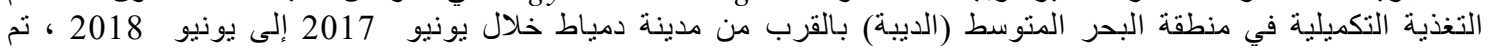

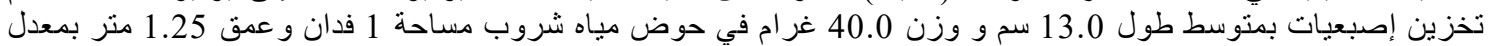

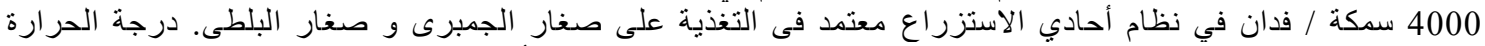

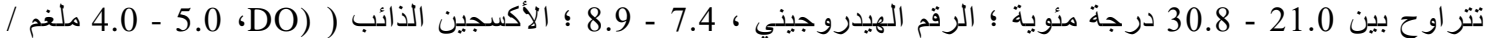

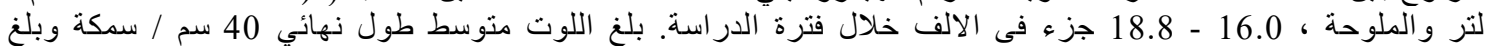

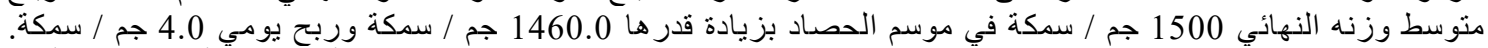

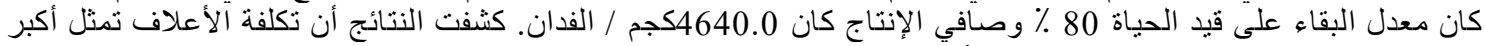

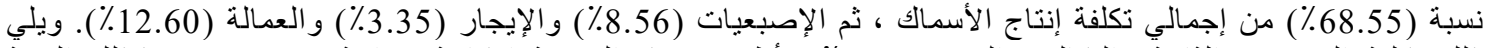

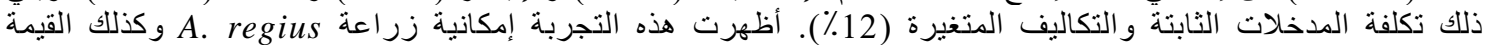

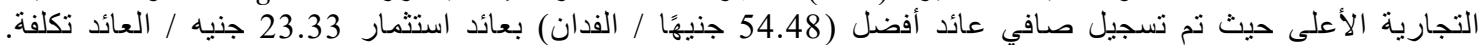
ويستنتج من هذه الدراسة ان سمك اللوت مربح جدا عند استزر اعه فى احو اض ارضيه في المياه الثروب . 